our knowledge of the first. But both operators represent objects of physical reality, so that by the definition it must be concluded either that the theory does not contain concepts for both, that is, it is incomplete, or else the two quantities have not physical reality at the same time. In quantum mechanics it is assumed that the wave function contains a complete description of this reality for the state to which it corresponds. This is reasonable, since the information obtainable from this function corresponds exactly to that which can be predicted with certainty without altering the state of the system.

In the final stage of the argument, an appeal is made to the process known as reduction of the wave packet. We must refer to the original paper for the details, but it is deduced that it is possible to predict with certainty two quantities corresponding to physical realities, and moreover that these quantities are represented by non-commuting operators. Thus we have to admit that if the quantum theory is complete and therefore contains concepts for these quantities then, although noncommuting, they correspond simultaneously to physical realities.

We saw that the uncertainty principle presented us with two alternatives; and now we see that if we deny the first of these alternatives, we have also to deny the second. The conclusion is that the first alternative, that the quantum theory is incomplete, has to be accepted.

It is possible that the criticism does not strike at the root of the quantum theory, since so much depends upon a definition of physical reality, which is not of necessity included in the theory. If we could be satisfied that the definition is necessary or that without it two simultaneous conjugate physical quantities are represented by commuting variables, then the quantum theory fails. An interesting letter on this point from Prof. G. Temple appears in Nature of June 8 (p. 957).

The paper by Einstein and his collaborators is rather to be regarded as an appeal for a more direct description of the phenomena of physics. The authors seem to prefer the artists' portrayal of the landscape rather than a conventional representation of its detail by symbols which bear no relation to its form and colour. The expression of a belief that it is possible to provide a complete description of physical reality indicates the nature and purpose of the criticism. Presumably the appeal is for a replacement of the operator calculus of the quantum theory by a method of description which resembles that of the classical and relativistic theories in that, like them, it introduces concepts more directly corresponding to physical realities.

In criticising quantum mechanics in this way, we must remember that it arose out of the inadequacy of existing models, and it has evolved in its particular way because it has had to do without them. The theory has done what, in the face of difficulty, it set out to do. It does not profess to describe actual phenomena but the possible results of measurements, and it is particularly concerned with the influence of the observer on the quantities observed. Much work is being done at present on the notation of the quantum theory. There are difficulties to be removed and with their removal we may find that we have travelled in the direction desired by the three authors. Physicists can scarcely remain content with a situation in which the electron is an equation, and the remark sometimes heard that the school of quantum mechanies is content to establish itself merely as a bureau for ready reckoning is by no means true. H. T. F.

\title{
U.S. Stratosphere Balloon Explorer II
}

\begin{abstract}
A BRIEF reference was made in NATURE of A February 23, p. 299, to the remarkable preparations afoot in the United States to launch a new attempt in stratosphere research following on the mishap to Explorer I. News has now come to hand that everything was ready by June 1 and the balloonists are only awaiting favourable weather conditions. The outstanding feature of this new experiment is the display of co-ordination of effort on the part of the National Geographic Society, the U.S. Army Air Corps and many of the public bodies interested in research. Capts. A. W. Stevens and O. A. Anderson will again ascend, and Capt. R. P. Williams is in charge of ground operations and has been named as alternative pilot.
\end{abstract}

Some idea of the magnitude of the task can be gained from the following details of the balloon and the experiments.

\section{BALLOON}

This was built and designed by the Goodyear Zeppelin Corporation, Ohio. When inflated it is $192 \mathrm{ft}$. in diameter and has a capacity of $3,700,000$ cub. ft. and an area of $2 \frac{2}{3}$ acres. Its initial charge will be $300,000 \mathrm{cub}$. ft. of helium, and with this 'bubble' of gas in it the top will rise $316 \mathrm{ft}$. from the ground when it is all complete and ready to start. The envelope is made of rubberised fabric, most of it weighing $5 \cdot 3 \mathrm{oz}$. a square yard, at the top $7 \cdot 2 \mathrm{oz}$. a square yard. The gas can be released 
by two pneumatically operated valves near the top and there are four inverted open canvas chimneys in the bottom, $7.5 \mathrm{ft}$. in diameter and $17 \mathrm{ft}$. long, to relieve it of surplus gas when fully inflated by the reduction of the external pressure.

The total lift of the balloon on the ground is more than 8 tons. This figure includes the weight of the balloon itself, men, equipment and ballast. The gondola is $9 \mathrm{ft}$. in diameter and weighs $638 \mathrm{lb}$. empty. It is painted white both inside and externally above the equatorial plane and black below. An arm, $14 \mathrm{ft}$. long, extends horizontally from it carrying a fan on the end, which supplies a tangential force to rotate the whole balloon. The gondola is provided with an $80 \mathrm{ft}$. round point triangular parachute operated by a pilot parachute to draw it from its bag.

\section{INSTRUMENTS AND EQUIPMENT}

The bag is provided with a 3 -ft. dial thermometer near the top to be viewed directly from the gondola through porthole and vent. For cosmic ray studies, Prof. R. A. Millikan has supplied three ionisation chambers, one exposed, one in two inches of lead and one, weighing $600 \mathrm{lb}$., in four inches of lead. Dr. W. F. G. Swann has supplied counter sets for various elevations from the horizontal, a lead-shielded chamber for 'bursts' and a Wilson expansion chamber. Mr.
O. H. Gish has supplied an apparatus consisting of a vertical chimney external to the gondola $1 \mathrm{ft}$. in diameter and $3 \mathrm{ft}$. high for a continuous ion count of the external air. Sun, sky and earth brightness records will be taken from outside the gondola, and records made of temperature and barometric pressure with resistance thermometer and short mercurial barometer respectively. The readings of the latter will be further checked by vertical camera studies of the ground and transit circle observations of the balloon made from the ground.

The sun and sky light will be studied spectrographically both from within and without the gondola for ozone content of the stratosphere. Mention has already been made of the vertical camera for height observations, but other cameras will photograph the horizon to obtain the figure of the earth, and a motion picture camera is provided to record any moving events. Air samples will be taken and spores collected, and even cultures of fruit flies are to be exposed to the rigours of the stratosphere. Finally, the observers will be in continuous radio communication with the ground on a transmission of 13,050 kilocycles per second, and a study will be attempted of the diffraction by the horizon of two sets of modulated waves emitted from the gondola aerial at 56,000 kilocycles and 112,000 kilocycles a second respectively.

\section{News and Views}

\section{Retirement of Sir George Adam Smith}

WhEN the autumn term begins, the Very Rev. Sir George Adam Smith will retire from the principalship of the University of Aberdeen. His long service of twenty-six years as principal exceeds that of any of his predecessors since the present University arose from the union of "The King's College" and "The Earl Marischal's College" on the passing of the first Universities Act of 1858. He has watched and guided the University during a period of notable development, when a demand for specialisation has increased the teaching staff by the addition of nine professorial chairs, three readerships, and fortyseven lectureships; and when these changes, together with an increase in the number of students from 1,007 to 1,272 , have required considerable additions to the fabric of the University itself. Of equal importance for the future of education and of scientific research has been the formation of linkages binding the University as a working unit with other institutions. In the present year the former United Free Church College in Aberdeen has joined with the University, and co-operation of great promise for the development of biological investigation in the north takes place with the Rowett Institute for
Research in Animal Nutrition, the Macaulay Institute for Soil Research, the Scientific Laboratory of the Fishery Board for Scotland, and the Torry Research Station. In the course of another year a new and vital link between the teaching and clinical aspects of medical subjects will be completed at the new Infirmary. These developments, on which, in some directions, the future of the University depends, Sir George has guided with a tact and balance of mind and with a friendliness and humanity which have endeared him to his fellow-workers in the University ; and both town and University appreciate his services in ensuring that common appreciation, co-operation and goodwill unite the civic and academic interests of the community.

\section{Valentin Magnan}

THE eminent French psychiatrist, Valentin Jacques Joseph Magnan, the centenary of whose birth was celebrated on May 27 by a special meeting of the Société médico-psychologique, was born on March 16, 1835, at Perpignan, which was also the birthplace of three other celebrated French psychiatrists, Pinel, Esquirol and Falret. His medical education took place first at Lyons and then in Paris, where he 